\title{
Exploring the Determinants of Behavioral Outcome: A Study of Online Learning Among College Students in Mexico
}

\author{
Kishwar Joonas \\ Prairie View A\&M University
}

\author{
Ahmed Y. Mahfouz \\ Prairie View A\&M University \\ Claudia Jaquelina González-Trujillo \\ Universidad de Monterrey \\ Diana Dávila Ruiz \\ Universidad Anahuac
}

We investigated the effects of prior visits to a given web site, social media mode and learning style of Internet users on their Behavioral Outcome based on an online search task. Currently, little research attention is given to Mexico regarding this topic. The research methodology was a laboratory experiment conducted in a university in Mexico, with a total sample of 120 subjects. The experimental design was a randomized complete block design. There were eight block-treatment $(2 \times 4)$ effects, assigned randomly to the subjects. The data analysis of the results and contributions of the study are presented and interpreted within the framework of Kolb's experiential learning theory.

Keywords: pedagogy, learning theory, social media, interactivity, experimental design, consumer behavior, interdisciplinary, Mexico

\section{INTRODUCTION AND MODEL}

Kolb's Learning Theory (1984) explains the way in which users learn and process new information, and merge it with existing knowledge. This theory traces the manner in which users learn and solve problems through a cycle comprising concrete experience, reflective observation, leading to abstract concepts creating, and concluding with hypothesis testing via active experimentation. The first is the way in which a person reacts to new information on a "concrete-experience to abstract-conceptualization" continuum. Concrete experience connotes the "affect" element (i.e., senses and feelings). On the other hand, abstract conceptualization connotes the cognitive element (i.e., logic or reasoning). The second is the manner in which new information is processed, comprising a "reflective-observation to activeexperimentation" continuum. Reflective observation means watching passively, while active experimentation connotes trying new things. Further, while using social media, the mode may be either non 
participatory, or passive; or it may be participatory, or engaged mode. Literature describes the impact of learning style on learning outcomes, and also the impact of the use of social media on learning outcomes. There is scarce research attention to both these determinants of Behavioral Outcome in a single study.

In 2000, there were 22.8 million students in Mexico within the formal education system grew over eight times from the 1950 level. This number grew to 36.3 million students in 2016, representing almost a 30 per cent of the country's population. Moreover, in 2016, over 31 percent of college-age students are enrolled in institutions of higher education (Magaziner and Monroy, 2016). According to July 2018 estimates, 82.8 million persons, or 65.77 per cent of the population, were connected to the Internet (U.S. Central Intelligence Agency, 2021), which would provide access to learning from social media. However, there is little research attention to learning and its determinants in Mexico. We propose to bridge this gap through investigating a model explicated in Figure 1 below.

\section{FIGURE 1 RESEARCH MODEL}

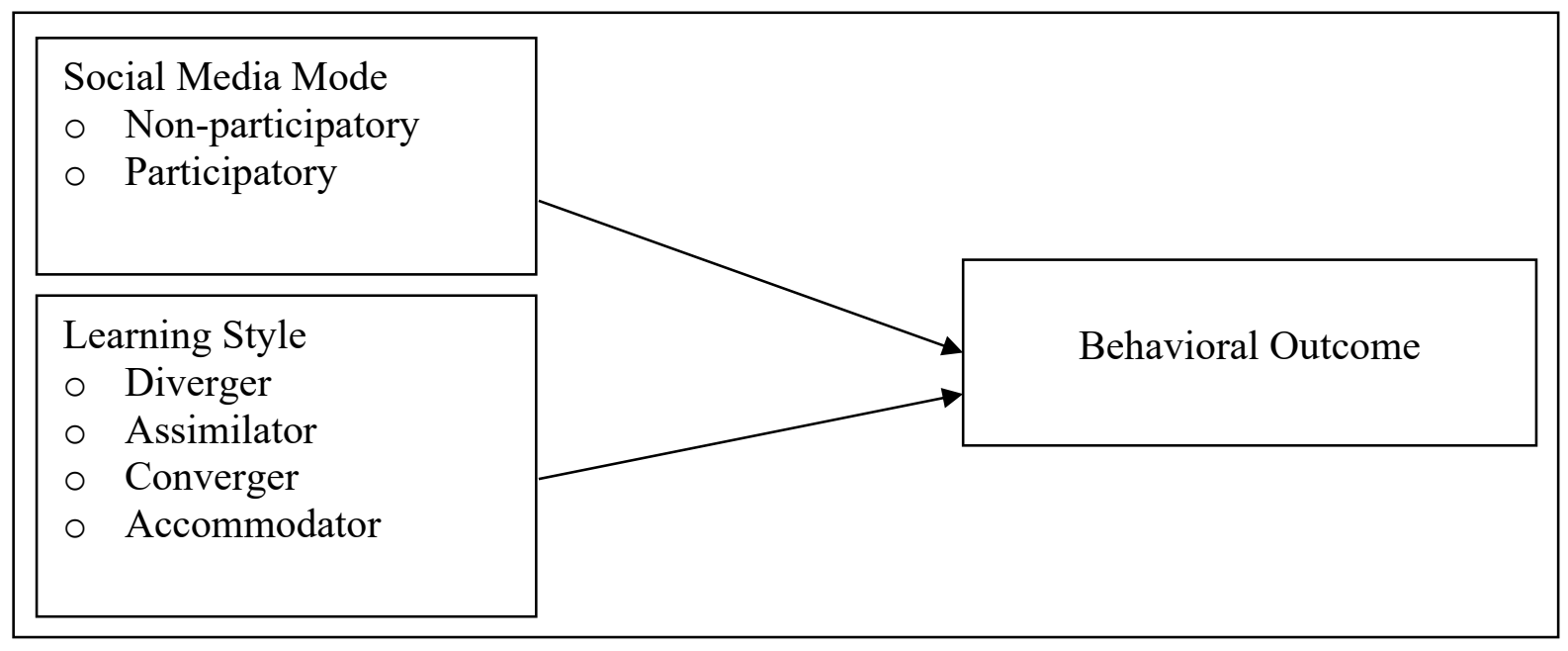

\section{THEORETICAL BACKGROUND}

Current research addresses online consumers' learning through engagement with a web site. Our understanding of learning is grounded in classical and neo-classical learning theories that emerged from Pavlovian experiments (Pavlov, 1927). Today, the role of classical conditioning though repetition, as well as instrumental or operant conditioning through incentivized advertising and reinforcement schedules in the creation of consumer behavior is widely recognized and applied (e.g., Schiffman and Wisenblit, 2019). Web developers ensure a high level of engagement with their site, through "cyberbait", comprising financial, convenience, and value incentives. Financial incentives garner first-time purchasers, by reducing the price, offering free shipping, or e-coupons, which are changed frequently to remain interesting to the online consumer (Clow and Baack, 2018). Convenience incentives comprise offering around the clock availability, detailed product information, ease of identifying and locating products, and other convenience services such as gift registries, related items. To shape long-term purchase behavior, value-added incentives are offer personalized shopping, through exclusive availability of products online, free online courses, and free information useful to consumers. Interactive web sites encourage consumer engagement (Clow and Baack, 2018). Such involvement and engagement results in positive consumer behaviors, such as increased probability of revisits, recommending the web site to others, and making purchases (Dessart et al., 2016, Hollebeek et al., 2014, Schivinski et al., 2016, Vander Shee, Peltier, and Dahl. 2020, Vivek et al., 2014).

Traditional learning treats the student as a passive observer, and the objective is the transfer of "received knowledge". On the other hand, interactive learning finds theoretical moorings in writings such as the 
Critical Pedagogy thesis (Freire, 1968, available in a 2000 English translation), which calls for the liberation of students from oppression, and recognizes their role in the creation of knowledge. Another learning theory, Constructivism (Piaget, 1967), stresses the active engagement of learners in knowledge creation. As students gather additional knowledge, they need to reconcile it with their existing knowledge to create an "improved cognitive schema". Individual experience, along with subjective assumptions about the environment, form the pillars of knowledge. Students continually test their assumptions via social negotiation.

Further, the Constructivism paradigm was influenced by the Social Development Theory (SDC) or socioconstructivism (e.g., Vygotsky, 1978). SDC posits that development results from social interaction, and that socialization and social behavior impact consciousness and cognition. Social learning through social interaction determines development. In addition, Vygotsky envisages a "more knowledgeable other" (MKO), having a higher level of comprehension or capability than the learner, with respect to a given task, process, or concept - possibly a fellow peer, someone younger, or even a computer. Finally, the zone of proximal development (ZDP) is defined as the distance between the student's ability to accomplish the task with or without peer collaboration. Initially, humans use culture-based tools to communicate needs; later, they internalize these tools, thereby attaining higher thinking skills, and the ZDP is zone where learning occurs. Thus, learning stems the relationship between humans and the sociocultural context in which they interact and behave in shared fields of experience. SDC advocates learning environments wherein the student engages in active learning. Reciprocity, or teacher-student collaboration serves to help the student in constructing meaning. An extension of the Constructivist theme is the Social Constructivist Perspective (SCP) (e.g., Palincsar, 1998) via reciprocity, collaboration, and reflection. Several studies have applied these concepts in recent studies in the academic field (e.g., Joonas, 2016, Joonas, 2018).

Moreover, as shown in Figure 2, Kolb's Learning Theory (Kolb, 1984; Kolb, Boyatzis, and Mainemelis, 2000; Kolb and Kolb, 2009, 2010, 2011) explains the way in which users learn and process new information, and merge it with existing knowledge. This theory traces the manner in which users learn and solve problems through a cycle comprising concrete experience, reflective observation, leading to abstract concepts creating, and concluding with hypothesis testing via active experimentation. The first is the way in which a person reacts to new information on a "concrete-experience to abstract-conceptualization" continuum. Concrete experience connotes the "affect" element (i.e., senses and feelings). On the other hand, abstract conceptualization connotes the cognitive element (i.e., logic or reasoning). The second is the manner in which new information is processed, comprising a "reflective-observation to activeexperimentation" continuum. Reflective observation means watching passively, while active experimentation connotes trying new things. Figure 2 provides a diagrammatic representation of Kolb's Experiential Learning Theory and Learning Styles.

According to Kolb's Experiential Learning Theory or Learning Style Inventory (1984), a Diverger is typified in applying their own senses and intuition, remaining a passive observer, reflecting on events, rather than participating (as an example: psychology students). An Assimilator is typified a being the most detached, and being a passive observer; whose perception occurs through symbolic representations and thought (as in the case of astronomers). A Converger is typified as the opposite of a Diverger - one who thinks about what is experienced, flowing from reason and analytical skills, through direct participation (as an example, mathematicians and engineers). Finally, an Accommodator is typified as relying on senses and intuition (similar to a Diverger), but one who learns hands-on through active participation (as in the case of social workers, educationists, and students of history).

Despite extensive writings supporting Kolb's Experiential Learning Theory, several researchers have questioned its efficacy as a predictor of behavior. As an example, some studies found very little support for the merits of using learning styles as a basis for content presentation (e.g., Kozub, 2010, Hodges and Evans, 1983, Trout and Crawley, 1985). When pedagogical methods were matched with student preferences, there was an effect on student attitudes, but not on student behavior (Trout and Crawley, 1985). At least one study that matched instructional strategies with learning styles, found only partial for the effect on enhanced performance outcome (Hodges and Evans, 1983). In a study of instructional design, no evidence was found of the impact of learning styles on student outcomes (Kobuz, 2010). 
FIGURE 2

KOLB'S EXPERIENTIAL LEARNING THEORY AND LEARNING STYLES

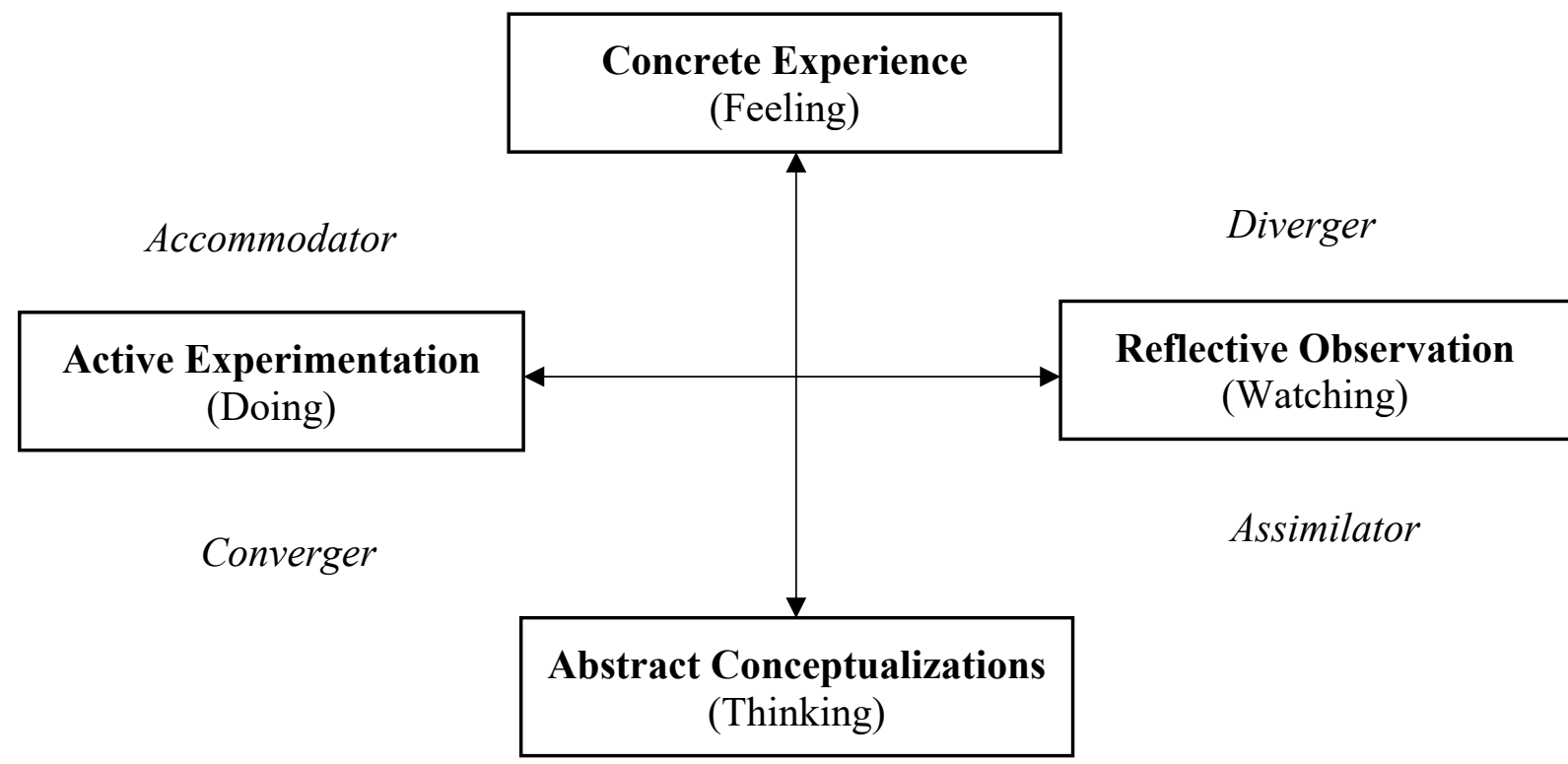

In this context, the digital environment provides numerous tools for social interactivity and collaboration. A vast majority of Web users use social media. Younger users, in particular, comprising Millennials and Gen Xers, obtain most of their information from social media applications such as Facebook and Twitter. In relation to social media, especially Generation Y or the Millennial Generation, is of current research interest. With its members being typically referred to as "digital natives" (Prensky, 2001), because this generation was born into the digital age, their daily life is dominated by information technology (e.g., Bennett, Maton, and Kervin, 2008; Wesner and Miller, 2008). This cohort identifies, uses, and interacts with content via social media and almost spend their lives online, and its behavior heralds the "brave new world", making it a highly researched topic (Bolton et al. 2013). Further, Millennials are evidenced to be more interactive in their Internet use as consumers of products and services, significantly more than Gen Xers, both through smartphones as well as personal computers for engaging with brands and stores. In addition, they use smartphones to engage in social networking, but to a lesser degree than is the case with Gen Xers (Moore, 2012). Moreover, Millennials use interactive tools for fun, as well as accessing applications (Grant, 2005; Moore, 2012, Tsao and Steffes-Hansen, 2008). Millennials search for information through multiple means, including e-mail, smart phones, blogs, and apps. In recognition of the way in which modern users engage with learning, it is essential to supplement traditional tools, with social media tools for enhanced learning. Drawing on constructivism, Greenhow and Lewin (2015) proposed a theoretical model showing the impact of social media on learning, in settings with varying levels of formality and informality.

In relation to Kolb's learning cycle, as well as Kolb's learning styles, social media performs a similar function. An individual could be either a passive viewer, or an active participant. Social media learning tools such as Facebook, YouTube, Twitter, blogs, and wikis are versatile, and lend themselves to both learning modes- the non-participatory as well as the participatory. As an example, a person may either view or "consume" content, or actively upload content (i.e., the "watching" stage). On the other hand, Instagram is popular application for sharing pictures, while Pinterest can be used to access and save pictures and links, and to organize them. Thus, social media applications lend themselves to content consumption, browsing through information, or accessing available feeds, where the user remain in non-participatory mode. In addition, some social media allows for participation, which means that the user enters the "doing" stage. Further, experience of social media content can be interpreted to generate "feeling", which would spur 
reflective thinking. In addition, through active social interaction in participatory mode, "feeling" as concrete experiences could spiral into "thinking". Therefore, participatory as well as non-participatory social media can be said to fit with Kolb's Learning Theory.

Since this is an exploratory study, we do not set forth the following hypotheses in regard to online users in Mexico:

Hypothesis $\boldsymbol{H}_{01}$ : There will be no significant effect of a prior visit to a given web site, on Behavioral Outcome.

Hypothesis $\boldsymbol{H}_{11}$ : There will be a significant effect of a prior visit to a given web site, on Behavioral Outcome.

Hypothesis $\boldsymbol{H}_{02}$ : There will be no significant effect of Social Media Mode on Behavioral Outcome.

Hypothesis $\boldsymbol{H}_{12}$ : There will be a significant positive effect of Social Media Mode on Behavioral Outcome.

Hypothesis $\boldsymbol{H}_{03}$ : There will be no significant effect of Learning Style on Behavioral Outcome.

Hypothesis $\boldsymbol{H}_{13}$ : There will be a significant positive effect of Learning Style on Behavioral Outcome.

Hypothesis $\boldsymbol{H}_{04}$ : There will be no significant effect of the interaction of Social Media Mode and Learning Style on Behavioral Outcome.

Hypothesis $\boldsymbol{H}_{14}$ : There will be a significant positive effect of the interaction of Social Media Mode and Learning Style on Behavioral Outcome.

\section{RESEARCH METHODOLOGY}

This study was conducted to investigate the effects of prior visit to a given commercial web site, social media and learning style of Internet users on their Behavioral Outcome based on a search task, using a laboratory experiment to provide the investigators control in minimizing sources of errors from the observations and data, thereby reducing bias. A laboratory experiment would allow a higher level of rigor. Since the study reflected Millennials and Gen Z in nature, subjects comprised 120 college students at a Mexican university, which uses Blackboard as a learning management system. Subjects were randomly assigned to the treatments.

The first independent variable, prior visit to a popular commercial web site, was assessed by a simple "Yes"/" No" question, asked of all respondents.

The other two independent variables, Social Media Mode and learning style, were manipulated. The second independent variable, Social Media Mode had two levels, comprising Non-participatory (N) and Participatory (P) Social Media Mode. Subjects were randomly assigned to one of these two treatments. Subjects were given a search task to complete. The participatory group were able to use social media tools, such as wikis, blogs, YouTube, Facebook, and Twitter to complete their task. The Non-participatory social media treatment excluded those social media tools.

We used the Kolb Learning Style Inventory (Kolb, 1984 Version 3.1), which measures users' learning style preference by asking the respondents to rank-order four statements for each of the 12 items comprising the instrument. Two primary dimensions are created from the four stages of learning, ACCE is the dimension created by subtracting summated score for the Concrete Experience (CE) scale from summated Abstract Conceptualization (AC) score. The AERO dimension represents the difference between summated Active Experimentation (AE) score and summated Reflective Observation (RO) score. The resultant four quadrants created by the two dimensions stand for the four levels of learning styles. Divergers (DV) have low ACCE and low AERO scores, Convergers (CN) have high ACCE and high AERO scores, Assimilators 
(AS) have high ACCE and low AERO scores, and Accommodators (AC) have low ACCE and high AERO scores.

The dependent variable was Behavioral Outcome, a composite score on three behaviors on the questionnaire administered to students, based on their search task which involved searching an online site for products to complete the task: site revisit (the likelihood of revisiting the site in the future), recommendation to others (the likelihood of recommending the site to others), and future intention to buy (likelihood of intending to purchase an item from this site in the future)

The experimental design was a randomized complete block design, a technique that reduces errors, with learning styles comprising the blocks (e.g., Montgomery 2001). There were 2 levels of Social Media Mode and 4 levels of learning styles, resulting in a total of 8 treatments.

The experimental treatments are shown in Table 1 below.

TABLE 1

TREATMENT COMBINATIONS (MONTGOMERY, 2001)

\begin{tabular}{|c|c|c|c|}
\hline \multicolumn{2}{|c|}{$\begin{array}{c}\text { Learning Style } \\
\text { Quadrant }\end{array}$} & \multirow{2}{*}{$\begin{array}{l}\text { Social } \\
\text { Media } \\
\text { Mode }\end{array}$} & \multirow[t]{2}{*}{$\begin{array}{c}\text { Treatment Combination } \\
\text { Learning Style and Social Media Mode }\end{array}$} \\
\hline ACCE & AERO & & \\
\hline \multirow{2}{*}{ Low } & \multirow[t]{2}{*}{ Low } & NP & Diverger, Non-participatory Social Media Mode \\
\hline & & $\mathrm{P}$ & Diverger, Participatory Social Media Mode \\
\hline \multirow[t]{2}{*}{ High } & \multirow[t]{2}{*}{ Low } & NP & Assimilator, Non-participatory Social Media Mode \\
\hline & & $\mathrm{P}$ & Assimilator, Participatory Social Media Mode \\
\hline \multirow[t]{2}{*}{ High } & \multirow[t]{2}{*}{ High } & NP & Converger, Non-participatory Social Media Mode \\
\hline & & $\mathrm{P}$ & Converger, Participatory Social Media Mode \\
\hline \multirow[t]{2}{*}{ Low } & \multirow[t]{2}{*}{ High } & NP & Accommodator, Non-participatory Social Media Mode \\
\hline & & $\mathrm{P}$ & Accommodator, Participatory Social Media Mode \\
\hline
\end{tabular}

The experimental design is a technique that reduces errors, with learning styles comprising the blocks. The statistical model is shown in Figure 3.

FIGURE 3

STATISTICAL MODEL

\begin{tabular}{|c|c|}
\hline where & $\begin{aligned} y_{i j k} & =\mu+\tau_{i}+\beta_{j}+\varepsilon_{i j k} \\
i & =1,2,3,4 \\
j & =1,2 \\
k & =1,2, \ldots, \mathrm{n}\end{aligned}$ \\
\hline & $=$ the overall effect of Behavioral Outcome of the $k$ th subject \\
\hline$\mu$ & $=$ the overall mean effect \\
\hline$\tau_{i}$ & $=$ the effect of the $i$ th level of learning style \\
\hline$\beta_{j}$ & $=$ the effect of the $j$ th level of Social Media Mode \\
\hline$\varepsilon_{i j k}$ & $=$ the random error component \\
\hline
\end{tabular}

\section{Experimental Procedure}

At the beginning of the experimental session, subjects provided their demographic information. Next, they completed the Kolb's Learning Style Inventory (LSI) instrument, which was obtained by special permission. Based on their responses to Kolb's LSI, subjects were assigned to learning style. They were then randomly assigned to one of two Social Media Mode treatments to complete an online search task of a product of their choosing. Participatory social media subjects communicated about their experience including likes and dislikes via social media tools such as forums and chats on Blackboard and Facebook. 
Non-participatory social media subjects did not communicate on Backboard and Facebook. After that, all respondents completed a questionnaire to measure their Behavioral Outcome of the search task. The dependent variable, Behavioral Outcome was a composite of a three-item scale: site revisit, or likelihood of revisiting the site in the future, recommendation to others, or likelihood of recommending the site to others, and future intention to buy, or likelihood of intending to purchase an item from this site in the future.

\section{STATISTICAL ANALYSIS}

Data analysis was conducted through descriptive statistics, reliability analysis, factor analysis, a twoway analysis of variance (ANOVA).

\section{Sample Description}

The sample comprised 120 undergraduate students in a university in Mexico. A hundred per cent of the respondents were female. The largest age group was $69 \%$ between $19-21$ years, followed by $28 \%$ between 22-24 years. All respondents were degree-seeking or undergraduate students. Sixty-three percent reported using the Internet primarily for social media use, and 37\% reported using the Internet for school or shopping-related purposes. Prior access to the assigned web site was reported by a high proportion of respondents; this demographic was also positively related to the Behavioral Outcome. In a week, twentyeight percent spent 30-39 hours online, 27\% spent 20-29 hours online, $22 \%$ stated spending 40 hours or more online, $18 \%$ spent 10-19 hours online, and only 6\% spent 9 hours or less online. For Social Media Mode, each treatment - participatory and non-participatory - had 60 subjects (i.e., each treatment comprised $50 \%$ of the subjects). (Appendix A).

\section{Distribution of Learning Styles}

As described above, Divergers (DV) have low ACCE and low AERO scores, Convergers (CN) have high ACCE and high AERO scores, Assimilators (AS) have high ACCE and low AERO scores, and Accommodators (AC) have low ACCE and high AERO scores. Respondents were classified according to their learning style reported via Kolb's LSI. Their distribution in the sample was as follows: $44.37 \%$ were Convergers, 24\% were Accommodators, an equal percentage (24) were Assimilators, and only 15\% were Divergers (Figure 4).

\section{FIGURE 4}

\section{SAMPLE'S DISTRIBUTION BY LEARNING STYLE}

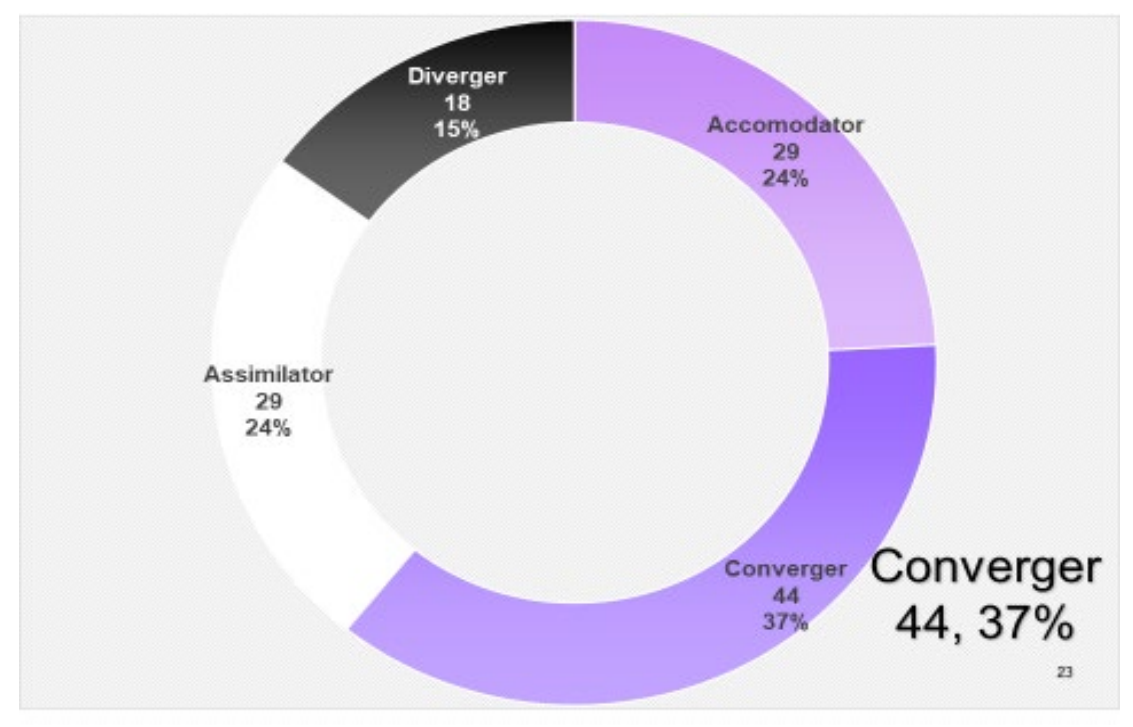




\section{Distribution of Treatment Combinations}

Respondents were classified according to their learning style reported via Kolb's LSI and Social Media Mode. As shown in Table 2, their distribution in the sample was the highest for Converger, Nonparticipatory Social Media Mode $(\mathrm{N}=29$, or 24.17), followed by Accommodator, Participatory Social Media Mode ( $\mathrm{N}=22,18.33 \%)$, Assimilator, Non-participatory Social Media Mode $(\mathrm{N}=16,13.33 \%)$, and Converger, Participatory Social Media Mode ( $\mathrm{N}=15,12.5 \%)$. Respondents' distribution in the sample was the lowest for Accommodator, Non-participatory Social Media Mode $(\mathrm{N}=7,5.83 \%)$, followed by Diverger, Non-participatory Social Media Mode ( $=8,6.67 \%)$, Diverger, Participatory Social Media Mode ( $=10$, and Assimilator, Participatory Social Media Mode (N=13, 10.83\%). (Table 2)

TABLE 2

SAMPLE'S DISTRIBUTION OF TREATMENT COMBINATIONS

\begin{tabular}{|c|c|c|l|c|c|}
\hline $\begin{array}{c}\text { Learning } \\
\text { Style } \\
\text { Quadrant }\end{array}$ & $\begin{array}{c}\text { Social } \\
\text { Media } \\
\text { Mode }\end{array}$ & \multicolumn{1}{|c|}{$\begin{array}{c}\text { Treatment Combination } \\
\text { Learning Style and Social Media Mode }\end{array}$} & Frequency & $\begin{array}{c}\text { Proportion } \\
\text { (\%) }\end{array}$ \\
\hline Low & Low & $\mathrm{NP}$ & Diverger, Non-participatory Social Media Mode & 8 & 6.67 \\
\cline { 3 - 6 } & $\mathrm{P}$ & Diverger, Participatory Social Media Mode & 10 & 8.33 \\
\hline \multirow{2}{*}{ High } & \multirow{2}{*}{ Low } & $\mathrm{NP}$ & $\begin{array}{l}\text { Assimilator, Non-participatory Social Media } \\
\text { Mode }\end{array}$ & 16 & 13.33 \\
\cline { 3 - 6 } & $\mathrm{P}$ & Assimilator, Participatory Social Media Mode & 13 & 10.83 \\
\hline High & \multirow{2}{*}{ High } & $\mathrm{NP}$ & Converger, Non-participatory Social Media Mode & 29 & 24.17 \\
\cline { 3 - 6 } & $\mathrm{P}$ & Converger, Participatory Social Media Mode & 15 & 12.50 \\
\hline \multirow{2}{*}{ Low } & \multirow{2}{*}{ High } & $\mathrm{NP}$ & $\begin{array}{l}\text { Accommodator, Non-participatory Social Media } \\
\text { Mode }\end{array}$ & 7 & 5.83 \\
\cline { 3 - 6 } & $\mathrm{P}$ & Accommodator, Participatory Social Media Mode & 22 & 18.33 \\
\hline & & Total & 120 & 100.00 \\
\hline
\end{tabular}

\section{Reliability}

Reliability is the extent to which an item, scale, or instrument will produce the same values when given at different times, places, or populations (Cronbach, 1951; Garson, 2012; Nunnally \& Bernstein, 1994). For the present study, reliability was established for the Behavioral Outcomes scale, and was found to be high, with Cronbach's alpha $=0.92$ (Table 3).

TABLE 3

RELIABILITY ANALYSIS: BEHAVIORAL OUTCOME

$\mathrm{N}=120$, cases excluded listwise

\begin{tabular}{|l|c|c|c|c|c|c|}
\hline \multicolumn{1}{|c|}{ Simple Statistics } \\
\hline & Nariable & Mean & $\begin{array}{c}\text { Std } \\
\text { Dev }\end{array}$ & Sum & Minimum & Maximum \\
\hline Behavior 1 - Revisit site & 120 & 5.69167 & 1.55459 & 683.00000 & 1.00000 & 7.00000 \\
\hline Behavior 2 - Recommend site & 120 & 5.79167 & 1.46038 & 695.00000 & 2.00000 & 7.00000 \\
\hline $\begin{array}{l}\text { Behavior 3 - Intend to purchase from this } \\
\text { site }\end{array}$ & 120 & 5.55833 & 1.72376 & 667.00000 & 1.00000 & 7.00000 \\
\hline
\end{tabular}




\begin{tabular}{|l|c|}
\hline \multicolumn{2}{|c|}{ Cronbach Coefficient Alpha } \\
\hline \multicolumn{1}{|c|}{ Variables } & Alpha \\
\hline Raw & 0.915505 \\
\hline Standardized & 0.919708 \\
\hline
\end{tabular}

\section{Validity}

When we are measuring what we claim to be measuring, it is referred to as validity. In this study, construct validity was achieved through the literature review, as well as by using the Kolb Learning Style Inventory (LSI) Version 3.1, which has been validated in the literature. Statistical validity was ensured via conducting exploratory factor analysis using principal components analysis with varimax rotation. Variables / scale items were retained under a factor, as long as it fell on its corresponding factor from the original scale (Kolb's LSI, and the Behavioral Outcomes scale), and had a factor loading value $>=\mid .50$. Interpretation of factors correspond to each learning style (Factor 1: Diverger, Factor 2: Assimilator, Factor 3: Converger, Factor 4: Accommodator), and Behavioral Outcome (Factor 5). For Kolb's LSI, using Equimax rotation, variance explained by each factor was Diverger $=5.11$, Assimilator -4.42 , Converger $=$ 4.31, and Accommodator $=3.97$, with final communality estimates total $=17.81$. Based on this, all scale items were retained for analysis (Table 4). It may be noted that items listed in Table 4 from the proprietary Kolb Learning Style Inventory (LSI) Version 3.1, are as defined in its use instructions, and authors are prohibited from disclosing the exact items.

TABLE 4

EXPLORATORY FACTOR ANALYSIS: KOLB'S LEARNING STYLE INVENTORY AND BEHAVIORAL OUTCOME

\begin{tabular}{|c|c|c|c|c|c|c|}
\hline \multicolumn{2}{|c|}{ Variable } & \multicolumn{5}{|c|}{ Factor and Factor Loading } \\
\hline & & Factor 1 & Factor 2 & Factor 3 & Factor 4 & Factor 5 \\
\hline \multirow{17}{*}{$\begin{array}{l}\text { Learning } \\
\text { Style } \\
\text { Inventory }\end{array}$} & RO_11B & .75 & & & & \\
\hline & $\mathrm{RO} \_6 \mathrm{~A}$ & .71 & & & & \\
\hline & $\mathrm{RO} 4 \mathrm{C}$ & .63 & & & & \\
\hline & $\mathrm{RO} \_7 \mathrm{~A}$ & .50 & & & & \\
\hline & $\mathrm{RO} \_12 \mathrm{C}$ & .50 & & & & \\
\hline & $\mathrm{CE} 2 \mathrm{C}$ & & .72 & & & \\
\hline & CE 9B & & .63 & & & \\
\hline & CE_4A & & .60 & & & \\
\hline & CE 6C & & .57 & & & \\
\hline & CE_1A & & .56 & & & \\
\hline & $\mathrm{AC} \_4 \mathrm{D}$ & & & .60 & & \\
\hline & $\mathrm{AC} 6 \mathrm{D}$ & & & .57 & & \\
\hline & $\mathrm{AC}$ _7D & & & .55 & & \\
\hline & $\mathrm{AC} \_12 \mathrm{~A}$ & & & .51 & & \\
\hline & $\mathrm{AE} \_\mathrm{CC}$ & & & & .66 & \\
\hline & AE_5D & & & & .65 & \\
\hline & $\mathrm{AE}$ 4B & & & & .52 & \\
\hline \multirow{3}{*}{$\begin{array}{l}\text { Behavioral } \\
\text { Outcome }\end{array}$} & Bhvr1 & & & & & .98 \\
\hline & Bhvr2 & & & & & .91 \\
\hline & Bhvr3 & & & & & .79 \\
\hline
\end{tabular}




\section{RESULTS}

As explained above, items for Behavioral Outcome were measured on a three-item Likert scale, with anchors $1=$ strongly disagree (rating "Very low"), and 7 = strongly agree (rating "Very high"). The highest Behavioral Outcome was "High" for recommending the site (Bhvr_2, 'I would recommend this site to others') with $\mathrm{M}=5.8, \mathrm{SD}=1.5, \mathrm{~N}=120$. The second highest Behavioral Outcome was "High" for site revisit (Bhvr1, 'I would revisit this site again') with $\mathrm{M}=5.7, \mathrm{SD}=1.6, \mathrm{~N}=120$. The smallest Behavioral Outcome was "High" for purchase intent (Bhvr_3, 'I intend to purchase an item from this site in future'), with $\mathrm{M}=5.6, \mathrm{SD}=1.7 . \mathrm{n}=120$ (Appendix B).

Results revealed an effect on Behavioral Outcome for those who had visited the given web site prior to taking the survey, in comparison with those that had not visited the site prior to the survey. A significant effect was found on Behavioral Outcome for those who visited versus those that have not visited the site. The mean for Behavioral Outcome is higher for those who visited the site $(\mathrm{N}=92)$ than for those who did not visit the site $(\mathrm{N}=28)$, with $\mathrm{M}=6.03$ versus 4.52 on a 7.0 Likert scale, respectively, and the $\mathrm{SD}=1.05$ versus 1.98, respectively (Appendix B). A significant effect of a prior visit to the web site was found on Behavioral Outcome for those who visited the site, versus those who had not visited the site prior to the survey $[\mathrm{F}(1,119)=27.97, \mathrm{p}<.001]$. The relationship between a prior visit to the given web site and Behavioral Outcome is significant and positive $\left(\mathrm{r}^{2}=0.1916, \mathrm{p}<.001, \mathrm{n}=120\right)$. Results suggest that this demographic explains $19.16 \%$ of the variance in Behavioral Outcome, and respondents who visited the web site in the past are more likely to revisit it, recommend it to friends and family, and are more likely to make a purchase. Results support Hypothesis $\mathrm{H}_{11}$ : A prior visit to a given web site has a significant and positive effect on Behavioral Outcome. This finding underlines the need for web developers to make their sites attractive, and introduce features that continue to encourage return visits (Table 5).

TABLE 5

ANOVA: BEHAVIORAL OUTCOME FOR PRIOR VISIT TO GIVEN WEB SITE

\begin{tabular}{|l|c|c|c|c|c|}
\hline Source & DF & Sum of Squares & Mean Square & F Value & Pr $>$ F \\
\hline Model & 1 & 48.8998510 & 48.8998510 & 27.97 & $<.0001$ \\
\hline Error & 118 & 206.2871357 & 1.7481961 & & \\
\hline Corrected Total & 119 & 255.1869867 & & & \\
\hline
\end{tabular}

\begin{tabular}{|c|c|c|c|}
\hline R-Square & Coeff Var & Root MSE & Behavioral Outcome Mean \\
\hline 0.191624 & 23.27669 & 1.322194 & 5.680333 \\
\hline
\end{tabular}

\begin{tabular}{|l|c|c|c|c|c|}
\hline Source & DF & Type III SS & Mean Square & F Value & Pr $>$ F \\
\hline VISIT_SITE & 1 & 48.89985095 & 48.89985095 & 27.97 & $<.0001$ \\
\hline
\end{tabular}

\begin{tabular}{|r|c|c|c|c|}
\hline VISIT_SITE & Frequency & Percent & Cumulative Frequency & Cumulative Percent \\
\hline $\mathbf{1}$ & 92 & 76.67 & 92 & 76.67 \\
\hline $\mathbf{2}$ & 28 & 23.33 & 120 & 100.00 \\
\hline
\end{tabular}

As shown in Appendix B, the learning style with greatest Behavioral Outcome was "Very high" for Divergers $(\mathrm{M}=6.1, \mathrm{SD}=1.2, \mathrm{n}=18)$. As discussed above, the Diverger stays a passive observer, who reflects on events, and applies their own senses an intuition while learning. For all the other three learning 
styles, Behavioral Outcome was "High". The learning style with the second highest Behavioral Outcome was for Accommodators $(\mathrm{M}=5.7, \mathrm{SD}, 1.5, \mathrm{~N}=29)$. According to research, the Accommodator relies on senses and intuition, but learns hands-on through active participation. The third highest Behavioral Outcome was for Convergers $(\mathrm{M}=5.6, \mathrm{SD}=1.5, \mathrm{n}=44)$. As described earlier, the greatest proportion of sample was Convergers (44. 37\%). Literature defines the Converger as someone who thinks about their experience, based on reason and analytical skills, through direct participation. The lowest Behavioral Outcome was for Assimilators $(\mathrm{M}=5.5, \mathrm{SD}=1.5, \mathrm{~N}=29)$.

As would be expected, based on Kolb (1984), we found that Accommodators have greater Behavioral Outcome than Assimilators, as well as Convergers. Also, we found that Convergers have greater Behavioral Outcome than Assimilators. In addition, we found that Divergers, who are the most detached, have greater Behavioral Outcome than Assimilators. However, we found that Divergers have a greater Behavioral Outcome than Convergers, and Divergers have a greater Behavioral Outcome than Accommodators (Appendix B).

The Behavioral Outcome was "High" for both participatory as well as non-participatory Social Media Mode. Our study confirms and extends extant literature (e.g., Bolton, Parasuraman, Hoefnagels, Migchel, Kabayadi, et al. 2013). Social Media Mode with a greater Behavioral Outcome was participatory mode (M $=5.8, \mathrm{SD}=1.5, \mathrm{n}=60$ ), or subjects using social media tools, such as Blackboard (forums and chat) and Facebook, in comparison with non-participatory mode $(\mathrm{M}=5.6, \mathrm{SD}=1.4, \mathrm{n}=60)$ (Appendix $\mathrm{B})$.

As shown in Table 10, Behavioral Outcome was "Very high" for the treatment Diverger, Participatory Social Media Mode, and was "High" for all the other seven treatment combinations. The highest Behavioral outcome for treatment was for Diverger, Participatory Social Media Mode $(\mathrm{M}=6.27, \mathrm{SD}=1.00, \mathrm{~N}=10)$, followed by Diverger, Non-participatory Social Media Mode $(\mathrm{M}=5.88, \mathrm{SD}=1.53, \mathrm{n}=8)$, Accommodator, Participatory Social Media Mode $(M=5.83, S D=1.62, n=22)$, Converger, Participatory Social Media Mode $(\mathrm{M}=5.69, \mathrm{SD}=1.47, \mathrm{n}=15)$, and Assimilator, Non-participatory Social Media Mode $(\mathrm{M}=5.69$, $\mathrm{SD}=1.33, \mathrm{n}=16$ ). On the other hand, the lowest Behavioral Outcome was for Assimilator, Participatory $(\mathrm{M}=13, \mathrm{SD}=5.39, \mathrm{SD}=1.76, \mathrm{n}=13)$, followed by Accommodator, Non-participatory Social Media Mode $(\mathrm{M}=5.48, \mathrm{SD}=1.03, \mathrm{n}=7)$, and Converger, Non-participatory Social Media Mode $(\mathrm{M}=5.49, \mathrm{SD}$ $=1.55, \mathrm{n}=29$ ). Thus, for all learning styles - with the exception of Assimilator - Behavioral Outcome was higher with the use of Participatory Social Media Mode (Appendix B).

We stated earlier that participatory social media subjects communicated about their experience, including likes and dislikes, using social media tools like forums and chats on Blackboard and Facebook. Also, as discussed above, an Assimilator is the most detached among all learner types, and is a passive observer; with their perception taking place through symbolic representations and thought. Therefore, it is logical that their Behavioral Outcome would be enhanced by the lack of distractions of social media. Given participatory Social Media Mode resulted in the greatest Behavioral Outcome as stated above, it shows that Divergers, who are passive learners, were stimulated the most by interactive social media tools, and had the highest Behavioral Outcome. However, absolute means are not supported by test results.

ANOVA results revealed no significant effects of the variables of interest or their interaction, [F (7, $119)=0.44, p<.05]$. In addition, results did not support a significant effect of the treatment Social Media Mode on Behavioral Outcome, $[\mathrm{F}(1,119)=0.26, \mathrm{p}<.05]$. We fail to reject Hypothesis $\mathrm{H}_{02}$, and conclude that there is no significant effect of Social Media Mode on Behavioral Outcome. Further, we found no support for the effect of Learning Style on Behavioral Outcome, $[F(3,117)=0.56, p<.05]$. Based on this finding, we fail to reject Hypothesis $\mathrm{H}_{03}$, which stated that will be no significant effect of Learning Style on Behavioral Outcome, Finally, there was no evidence of the impact of interactional effects of Social Media Mode and Learning Style on Behavioral Outcome, $[\mathrm{F}(3,117)=0.32, \mathrm{p}<.05]$. Hence, we fail to reject Hypothesis $\mathrm{H}_{04}$, which stated that there will be no significant effect of the interaction of Social Media Mode and Learning Style on Behavioral Outcome (Table 6). 
TABLE 6

ANOVA: BEHAVIORAL OUTCOME FOR SOCIAL MEDIA MODE AND LEARNING STYLE

\begin{tabular}{|l|c|c|c|c|c|}
\hline Source & DF & Sum of Squares & Mean Square & F Value & Pr $>$ F \\
\hline Model & 7 & 6.8914491 & 0.9844927 & 0.44 & 0.8723 \\
\hline Error & 112 & 248.2955376 & 2.2169244 & & \\
\hline Corrected Total & 119 & 255.1869867 & & & \\
\hline
\end{tabular}

\begin{tabular}{|c|c|c|c|}
\hline R-Square & Coeff Var & Root MSE & Behavioral Outcome Mean \\
\hline 0.027005 & 26.21209 & 1.488934 & 5.680333 \\
\hline
\end{tabular}

\begin{tabular}{|l|c|c|c|c|c|}
\hline Source & DF & Type III SS & Mean Square & F Value & Pr $>$ F \\
\hline Treatment & 1 & 0.57444387 & 0.57444387 & 0.26 & 0.6117 \\
\hline Learning Style & 3 & 3.71598629 & 1.23866210 & 0.56 & 0.6434 \\
\hline Treatment*Learning Style & 3 & 2.12984636 & 0.70994879 & 0.32 & 0.8107 \\
\hline
\end{tabular}

\section{DISCUSSION AND CONCLUSIONS}

The sample of the present exploratory study comprised 120 respondents in Mexico. Future research may cover a larger sample size, as well as samples from different countries, to establish generalization. Our study was conducted in an experimental setting, and although it does help with internal validity through tighter control, a laboratory may not fully represent real-world scenarios. Our subjects comprised college students who are online users; however, they may not represent all Internet users, and findings may not be generalizable to all populations. In terms of homogeneity of the sample, $100 \%$ of the subjects were female; yet, this fact helps establish internal validity. Literature indicates the role of other determinants, notably gender, in Behavioral Outcome (e.g., Guillem and Mograss, 2005). It would be fruitful to conduct a study with a sample comprising males, and examine differences in Behavioral Outcome between the two samples.

Our finding on the role of a prior visit to a web site confirms and extends extant research. This finding is in line with the works on classical and neo-classical theories of learning (e.g., Pavlov, 1927), as well as their application in consumer behavior and communications (e.g., Schiffman and Wisenblit, 2019, Clow and Baack, 2018). In addition, our findings support the importance of engagement and involvement in creating positive behavioral outcomes (e.g., Dessart et al., 2016, Hollebeek et al., 2014, Schivinski et al., 2016, Vander Shee, Peltier, and Dahl. 2020, Vivek et al., 2014).

Social media is a powerful medium for young people to reach out, network, and exchange ideas and feedback. However, the use of social media might be related to feelings, emotions, and gratification, and not necessarily to Behavioral Outcome. Our findings seem to concur with some extant research (e.g., Kobuz, 2010, Hodges and Evans,1983, Trout and Crawley 1985). It appears that Kolb's Experiential Learning Theory may be interpreted as a preference, which need not necessarily translate into behavior. Learning Style might impact affect, or attitude, and this would be an area of research inquiry. With longterm use of learning strategies, online users' learning style might not be a critical factor in behavioral Outcome (e.g., Kobuz, 2010).

Our study has several research implications. The study extends existing research on the role of learning styles as well as social media in the creation of Behavioral Outcome. The study adds to knowledge about determinants of Behavioral Outcome among online users and consumers in Mexico, a country that has received scarce research attention. This research highlights the importance of repeat visits to a web site, on 
Behavioral Outcome. Moreover, our study is relevant to practitioners in various research fields, including psychology, education, organizational behavior, consumer behavior, marketing management, and public policy. Our study results will encourage educationists to examine the true role of social media in learning or search tasks. Instructional designers of learning management systems (such as Blackboard, Moodle, etc.) will benefit by looking beyond social media tools as well as learning styles of users, and explore other ways of engaging their audience, to encourage repeat visits to the site. Finally, our research will provide students with a better understanding of the limited effect of their own learning styles, and to question the use of social media, in impacting behavioral outcomes. Our research will encourage among students, the adoption of other, more effective learning strategies toward enhanced academic success, including frequent visits to

online course resources. Our study will be useful to developers of commercial sites and applications to focus on enhancing web site quality, so that consumers may increase their site revisits, site recommendation, and purchase intention.

\section{REFERENCES}

Bennett, S., Maton, K., \& Kervin, L. (2008). The 'digital natives' debate: A critical review of the evidence. British Journal of Educational Technology, 39(5), 775-786.

Bolton, R.N., Parasuraman, A., Hoefnagels, A., Migchels, N., Kabadayi, S., Gruber, T., . . Solnet, D. (2013). Understanding Generation Y and their use of social media: A review and research agenda. Journal of Service Management, 24(3), 245-267.

Clow, K.E., \& Baack, D. (2018). Integrated Advertising, Promotion, and Marketing Communications. Pearson Prentice-Hall: New York, NY.

Cronbach, L.J. (1951). Coefficient alpha and the internal structure of tests. Psychometrika, 16(3), 297334.

Dessart, L., Veloutsou, C., \& Morgan-Thomas, A. (2016). Capturing consumer engagement: Duality, dimensionality and measurement. Journal of Marketing Management, 32(5/6), 399-426.

Freire, P. (2000). Pedagogy of the oppressed (30th anniversary ed., M. B. Ramos, Trans.). New York, NY: Continuum. (Original work published 1970).

Garson, G.D. (2012). Hierarchical Linear Modeling: Guide and Applications. Thousand Oaks, CA: SAGE Publications, Inc.

Grant, I.C. (2005). Young people's relationships with online marketing practices: An intrusion too far? Journal of Marketing Management, 21(5/6), 607-23.

Greenhow, C., \& Lewin, C. (2015). Social media and education: Reconceptualizing the boundaries of formal and informal learning. Learning, Media and Technology, 41(1), 6-30.

Guillem, F., \& Mograss, M. (2005). Gender differences in memory processing: Evidence from event related potentials to faces. Brain and Cognition, 57(1), 84-92.

Hollebeek, L.D., Glynn, M.S., \& Brodie, R.J. (2014). Consumer brand engagement in social media: Conceptualization, scale development and validation. Journal of Interactive Marketing, 28(2), $149-165$.

Joonas, K. (2016). The Pygmalion Effect across academic levels in an HBCU: Reflections on service learning experiences. Journal of Higher Education Theory \& Practice, 16(2), 120-132.

Joonas, K. (2018). Guided Student Engagement Through Research and Consultancy: Structure, Evaluation and Prognosis. Southwest Business and Economics Journal, 25, 37-45.

Kolb, A.Y., \& Kolb, D.A. (2009). In S.J. Armstrong \& C. Fukami (Eds.), Experiential learning theory: A dynamic, holistic approach to management learning, education and development (p.50). In Handbook of Management Learning, Education and Development. London: Sage Publications.

Kolb, A.Y., \& Kolb, D.A. (2010). Learning to play, playing to learn: A case study of a ludic learning space. Journal of Organizational Change Management, 23(1), 26-50.

Kolb, A.Y., \& Kolb, D.A. (2011). Kolb Learning Style Inventory 4.0. Boston MA: Hay Group.

Kolb, D.A. (1984). Experiential Learning: Experience as the source of learning and development. Englewood Cliffs, N. J.: Prentice-Hall. 
Kolb, D.A., Boyatzis, R.E., \& Mainemelis, C. (2000). Experiential Learning Theory: Previous Research and New Directions. In Sternberg \& Zhang (Eds.), Perspectives on cognitive, learning, and thinking styles. NJ: Lawrence Erlbaum.

Kozub, R.M. (2010). An ANOVA Analysis of the Relationships between Business Students' Learning Styles and Effectiveness of Web Based Instruction. American Journal of Business Education, 3(3), 89-98.

Lentner, M., \& Bishop, T. (1993). Experimental Design and Analysis. Blacksburg, VA: Valley Book Company. The University of Alabama.

Magaziner, J., \& Monroy, C. (2016, August). Education in Mexico. World Education News and Reviews. Retrieved March 24, 2019, from http://wenr.wes.org/2016/08/education-in-mexico

Montgomery, D.G. (2001). Design and analysis of experiments. New York: John Wiley and Sons, Inc.

Moore, M. (2012). Interactive media usage among millennial consumers. The Journal of Consumer Marketing, 29(6), 436-444.

Nunnally, J.C., \& Bernstein, I.H. (1994). The Assessment of Reliability. Psychometric Theory (3rd ed., pp. 248-292). McGraw-Hill.

Palincsar, A.S. (1998). Social constructivist perspectives on teaching and learning. Annual Review of Psychology, 49(1), 345-375.

Pavlov, I.P. (1927). Conditioned reflexes. New York: Dover.

Piaget, J. (1967). Biologie et connaissance (Biology and knowledge). Paris: Gallimard.

Prensky, M. (2001). Digital natives, digital immigrants. On the Horizon, 9(5).

Schiffman, L.G., \& Wisenblit, J. (2019). Consumer Behavior (Twelfth edition). Pearson Education: Upper Saddle River, NJ.

Schivinski, B., Christodoulides, G., \& Dabrowski, D. (2016). Measuring consumers' engagement with brand-related social-media content: Development and validation of a scale that identifies levels of social-media engagement with brands. Journal of Advertising Research, 56(1), 64-80.

Tsao, J.C., \& Steffes-Hansen, S. (2008). Predictors for internet usage of teenagers in the United States: A multivariate analysis. Journal of Marketing Communications, 14(3), 171-191.

U.S. Central Intelligence Agency. (2021). Mexico - The World Factbook. Retrieved from https://www.cia.gov/the-world-factbook/countries/mexico/\#communications

Vander Schee, B.A., Peltier, J., \& Dahl, A.J. (2020). Antecedent consumer factors, consequential branding outcomes and measures of online consumer engagement: Current research and future directions. Journal of Research in Interactive Marketing, 14(2), 239-268.

Vivek, S.D., Beatty, S.E., Dalela, V., \& Morgan, R.M. (2014). A Generalized Multidimensional Scale for Measuring Customer Engagement. Journal of Marketing Theory and Practice, 22(4), 401-420.

Vygotsky, L. (1978). Interaction between Learning and Development. In M. Cole, V. John Steiner, S. Scribner, \& E. Souberman (Eds.), Mind in Society: The Development of Higher Psychological Processes. Cambridge, Massachusetts: Harvard University Press.

Wesner, M.S., \& Miller, T. (2008). Boomers and Millennials have much in common. Organizational Development, 26(3), 89-96. 


\section{APPENDIX A: SAMPLE DEMOGRAPHICS}

\begin{tabular}{|c|c|c|}
\hline \multicolumn{1}{|c|}{ Item } & Frequency & Proportion (\%) \\
\hline Gender & & 0 \\
\hline Male & 120 & 100 \\
\hline Female & & \\
\hline Age & 4 & 3 \\
\hline 18 & 83 & 69 \\
\hline $19-21$ & 33 & 28 \\
\hline $22-24$ & 6 & 0 \\
\hline $25-27$ & 1 & 0 \\
\hline $28+$ & & 100 \\
\hline Degree & 120 & 37 \\
\hline Bachelor's seeking & & 0 \\
\hline Internet Usage & 44 & 0 \\
\hline School/Shopping & 0 & 63 \\
\hline Games & 0 & \\
\hline News & 76 & \\
\hline Social Media & & \\
\hline
\end{tabular}

\begin{tabular}{|c|c|c|}
\hline Hours Online (Weekly) & & 6 \\
\hline 9 and under & 7 & 18 \\
\hline $10-19$ & 22 & 27 \\
\hline $20-29$ & 32 & 28 \\
\hline $30-39$ & 33 & 22 \\
\hline $40+$ & 26 & 6 \\
\hline
\end{tabular}


APPENDIX B: DESCRIPTIVE STATISTICS

\begin{tabular}{|c|c|c|c|c|c|}
\hline \multicolumn{2}{|c|}{ Variable } & \multicolumn{2}{|l|}{ Scale Item } & Mean & $\begin{array}{l}\text { Standard } \\
\text { Deviation }\end{array}$ \\
\hline \multirow{4}{*}{\multicolumn{2}{|c|}{ Behavioral Outcome }} & \multicolumn{2}{|l|}{ Behavior 1 - Revisit site } & 5.69 & 1.56 \\
\hline & & \multicolumn{2}{|c|}{ Behavior 2 - Recommend site } & 5.79 & 1.46 \\
\hline & & \multicolumn{2}{|c|}{$\begin{array}{l}\text { Behavior } 3 \text { - Intend to purchase } \\
\text { from this site }\end{array}$} & 5.56 & 1.74 \\
\hline & & \multicolumn{2}{|l|}{ Total $(\mathrm{N}=120)$} & 5.68 & 1.46 \\
\hline \multicolumn{6}{|c|}{\begin{tabular}{|l|l|}
\multicolumn{2}{|l|}{ Behavioral Outcome } \\
\end{tabular}} \\
\hline Variable & \multicolumn{2}{|c|}{ Scale Item } & $\mathbf{N}$ & Mean & $\begin{array}{l}\text { Standard } \\
\text { Deviation }\end{array}$ \\
\hline \multirow{2}{*}{$\begin{array}{l}\text { Prior Visit to } \\
\text { Given Web } \\
\text { Site }\end{array}$} & \multicolumn{2}{|l|}{ Visit 1 - Visited site } & 92 & 6.03 & 1.05 \\
\hline & \multicolumn{2}{|c|}{ Visit 2 - Did not visit site } & 28 & 4.52 & 1.98 \\
\hline \multirow{2}{*}{$\begin{array}{l}\text { Social Media } \\
\text { Mode }\end{array}$} & \multicolumn{2}{|l|}{ NP - Non-participatory } & 60 & 5.59 & 1.41 \\
\hline & \multicolumn{2}{|l|}{ P - Participatory } & 60 & 5.77 & 1.52 \\
\hline \multirow{4}{*}{$\begin{array}{l}\text { Learning } \\
\text { Style }\end{array}$} & \multicolumn{2}{|l|}{ AC - Accommodator } & 29 & 5.75 & 1.49 \\
\hline & \multicolumn{2}{|l|}{$\mathrm{CN}$ - Converger } & 44 & 5.56 & 1.51 \\
\hline & \multicolumn{2}{|l|}{ AS - Assimilator } & 29 & 5.54 & 1.52 \\
\hline & \multicolumn{2}{|l|}{ DV - Diverger } & 18 & 6.09 & 1.24 \\
\hline \multirow{8}{*}{$\begin{array}{l}\text { Level of } \\
\text { Treatment }\end{array}$} & AC - Accommodator & NP - Non-Participatory & 7 & 5.48 & 1.03 \\
\hline & $\mathrm{CN}-$ Converger & NP - Non-Participatory & 29 & 5.49 & 1.55 \\
\hline & AS - Assimilator & NP - Non-Participatory & 16 & 5.69 & 1.33 \\
\hline & DV - Diverger & NP - Non-Participatory & 8 & 5.88 & 1.53 \\
\hline & AC-Accommodator & P - Participatory & 22 & 5.83 & 1.62 \\
\hline & $\mathrm{CN}$ - Converger & P - Participatory & 15 & 5.69 & 1.47 \\
\hline & AS - Assimilator & P - Participatory & 13 & 5.36 & 1.76 \\
\hline & DV - Diverger & P - Participatory & 10 & 6.27 & 1.00 \\
\hline
\end{tabular}

